\title{
Natural History of Cow's Milk Allergy- An Eight-Year Follow-up Study in 115 Atopic Children
}

\author{
Arnaldo Cantani* \\ Pediatric Clinic, University “La Sapienza” Roma, Italy \\ Submission: January 20, 2017; Published: February 06, 2017 \\ *Corresponding author: Arnaldo Cantani, Pediatric Clinic, University “La Sapienza” Roma, Italy
}

\begin{abstract}
Background: Cow's milk allergy (CMA) is a disease of infancy and usually appears in the first few months of life. The evaluation of infants for possible CMA is one of the more common problems shared by pediatricians. The role of foods in determining and/or aggravating the clinical features of atopic dermatitis (AD) has been stressed in the last decades.

Objective: The aim of the present study was to investigate, in children with food relat?ed AD, the development of tolerance to the offending food (s), clinical or laboratory data to predict the development of food tolerance, and whether there are clinical or laboratory data to predict the onset of respiratory allergy.
\end{abstract}

Materials and methods: In this prospective study we report on 115 babies, first examined at a median age of 6 months, and followedup for 8 years. We have investigated several factors as predictive of the outcome, as follows: early onset; widespread or not-typical (reverse pattern) skin lesions, family history positive for atopy; persisting FA, high levels of total and specific IgE antibodies, association with CMA and asthma.

Results: All these parameters were signifiาcantly predictive of a long-term morbidity of AD chilᄀdren with CMA. The median age for tolerance to cow's milk was 7 years +11 months, to egg 6 years +6 months, and to wheat 7 years +2 months. However a great number of both tolerant and intolerant children developed multiple food sensitizations. Only 66 children (57\%) acquired food tolerance, but there was the onset of asthma in $54 \%$ of cases.

Conclusion: The natural history of CMA is not well-known, since not many related studies have been done in children. The several predictive factors, all in a negative sense, may be the norm in atopic children. We suggest possible areas of intervention in children at risk due to parental atopy. Preventive measures may induce a dramatic improvement in children with food allergy, but we stress that the long-term prognosis is challenging, since asthma prevalence may increase up to $54 \%$ during a long follow-up. Therefore, the natural his tory of IgEmediated AD in atopic children sensitized to several allergens may be less optimistic than generally reported.

Keywords: Cow's milk allergy; Food allergy; Food tolerance; Natural history Atopic dermatitis; Asthma; Children; Prognosis; Atopic march; Prevention

Abbreviations: AD: Atopic dermatitis; BM: Breast milk; CM: Cow's milk; CMA: Cow's milk allergy; FA: Food allergy; FH: Family history; GM: Geometric mean; MA: Median age; SCORAD: Severity scoring of atopic dermatitis; SD: Standard deviation; SPTs: Skin prick tests

\section{Introduction}

The natural history of CMA (cow's milk allergy) in children is not well-known, since several widely discussed genetic and environmental factors can influence the develop $\urcorner$ ment of atopic disease [1-5], also due to conflicting reports including different selection criteria, study design and data presentation, variations in patient selection. Differences may depend on whether the study group consists of infants at risk or unselected children, their age when studied, or the study is prospective or retrospective [6-36].

We have explored the natural evolution of CMA, associated or not with $\mathrm{AD}$ in 88 children, a median age of 36 months, and a

very high incidence of positiาve family history $(\mathrm{FH})$. They were affected with FA, as demonstrated by skin prick tests (SPTs) and/or RAST positive against the offending food(s) and positive responses to the elimination diets and challenge tests [3]. In this prospective study all children have been followed-up to evaluate the achieve $\urcorner$ ment of tolerance to the cau $\operatorname{sative}$ agent(s). At the final follow-up only $25 / 88$ children $(28 \%)$ tolerated the offending food, but 34/88 (38\%) exhibited other sensitizations, including 10/15 children with CMA and 4/15 with egg allergy. Both tolerant and not tolerant children have developed additional sensitizations with significant statistical differences between the children who lost FA and those with persisting FA. 
Moreover, 15 children with CMA achieved the tolerance at an age significantly higher compared to chil $\neg$ dren with allergy to other foods and 10/15 (67\%) have exhibited more sensitizations, primarily asthma during the follow-up.

We can therefore affirm that CMA can be viewed as an unfavorable prognostic factor, and as a clue of a marked atopic predisposition. The persisting intolerance to the offending food was significantly associated with symptoms such as angioedema and AD singularly or variously associated [3]. The data are at variance with the common reports quoting that FA, in the majority of cases, improves or clears at a (very) young age $[14,17,18,31,33-35]$. It is interesting to note that some foods, e.g. fish and nuts appear to induce more severe (as angioedema) and persisting clinical manifestations. This is not surprising since no child sensitive to these two foods lost food hypersensitivity [3]. As previously documented [3,4], other foods more often causing allergy are cow's milk (CM), egg, and wheat, which are among the most common foods consumed by children [17], thus explaining why the $\mathrm{AD}$ outcome is not so optimistic as generally affirmed [2-4].

In another prospective study [7], AD was due to $\mathrm{FA}$ in $82 \%$ of children sensitized to CM and egg in $69 \%$ of cases, while $43 \%$ of children still had $\mathrm{AD}$ at the last follow-up. Tolerance toward $\mathrm{CM}$ and egg was reached at age 4 years. In addition $54 \%$ of patients had bronchial asthma and/or allergic rhinitis (AR) during the follow-up. The studies on AD natural history have selected numerous factors as predictive of the outcome, which partly confirm the above alluded to results, as follows: early $[34,35]$ or late $\mathrm{AD}$ onset after the 6 th month of life $[7,19]$; widespread or not-typical (reverse pattern) skin lesions [7,14,15,18,19,32-35],, FH positive for atopy $[3,14,15,18,34,35]$, male $[3,15]$ or fe $\neg$ male $[19,34,35]$ sex; perาsisting FA (7), high levels of total and specific IgE [3] directed against relevant foods [17], association with CMA [36] a relationship between development of tolerance and symptoms and between tolerance and start of ad $\neg$ ditional allergies, all with statistical significant differences [3,7]. Positiาve SPTs and/or IgE antibodies to inhalant allergens at the first examination appeared to have a predictive value for the development of respiratory allergy $(p=0.0007)[7,22,23]$. In the present study we report that the natural history of IgE mediated FA is less favorable than previously observed $[14,17,18,31,33$ 35].

\section{Patients and Methods}

\section{A. Patients}

To ascertain the natural history of CMA, we have prospectively studied and followed-up for 8 years 115 children, 66 males, 49 females, aged 4-12 months (median 6.5 months) attending the Division of Allergy and Immuno $\neg$ logy of the Department of Pediatrics of the Roma University «La Sapienza» because of suspected CMA and AD. In these children, at the first visit a 4-week diagnostic elimination diet was prescribed for diagnostic purposes. $\mathrm{CM}$ and dairy products were avoided if $\mathrm{AD}$ appeared when $\mathrm{CM}$ was the only feeding. If $\mathrm{AD}$ occurred when egg and wheat were also given, these foods were avoided. Further foods were eliminated following anamnestic data. Soy-milk (SOM1, Milupa), home-made, lamb-meat based-diet, and other nutritionally adequate food equivalents were employed. An open food challenge (OFC) was done when skin lesions cleared-up. If no immediate reaction ensued, food was fed in a normal way, and the skin accurately checked by parents. At each visit the severity of skin lesions was evaluated. On the basis of OFCs results, a therapeutic elimination diet, excluding the offending foods, was given independently of IgE and/or SPTs responses. All patients were checked every year or more frequently if necessary.

We assessed whether the babies were «at risk» of atopic disease because of a positive $\mathrm{FH}$ of atopy since one or both parents and/or siblings suffered from asthma, or AD, or AR. For each child a detailed clinical history was recorded with particular reference to the additional parameters: type of alimentation at birth, including the duration of breastfeeding (if it was the case), median age (MA) at the onset of clinical manifestations (AD), and at first CM feeding, presence of skin lesions and/or respiratory allergy. The diagnosis of atopic diseases in the children was done according the following criteria: clinical history, physical examination and positive SPTs and/or RAST to the most common inhalant and/or food allergens. Informed consent was obtained from parents of each child.

\section{B. Skin prick test}

Appropriate emergency equipment and medications were available on site. Skin testing was done at baseline by the prick method by a doctor trained in allergy with the co-operation of a qualified nurse. The skin was marked with a ball $\neg$ point pen for the allergens to be tested. The babies were then tested with: histamine hydrochloride $(1 \mathrm{mg} / \mathrm{ml})$ as a positive control and isotonic saline as a negative control. We continued with a battery of food aller-gens, including whole CM protein, casein, lactalbumin, egg, fish, wheat, soy, Dermatophagoides pteronyssinus, Alternaria alternata, Lolium perenne, Olea europea and Parietaria officinal is (SARM, Roma, Italy). The diagnostic extract of each individual allergen was placed on the volar surface of the forearm as drops through which the skin was superficially pricked with a straight pin for one second. A new pin was used for each prick test and then discarded, and the drop of the extract was then wiped off about one minute after the prick [24].

\section{SPTs were read at 20 minutes and considered positive as follows}

+ When the wheal was the half of the histamine wheal;

++ when the wheal was equal to the histamine wheal;

+++ when the wheal was two-fold the histamine wheal;

++++ When the wheal was more than two-fold the histamine wheal [25]. 
We took for positive only children with a +++ or ++++ reaction, that is a wheal $33 \mathrm{~mm}$ with an area $=7 \mathrm{~mm} 2$ (cut-off). So we considered as positive only the children with a mean wheal diameter of $3 \mathrm{~mm}$ or larger than the nega-tive (saline) control. A positive (histamine) control was performed to ensure the absence of any antihistamine drug interference [26].

\section{Total IgE}

The determination of total serum IgE levels was done by paper radioimmunosorbent test (PRIST, Pharmacia Diagnostics $\mathrm{AB}$, Sweden), and results were given in International Units (IU)/ml, usually expressed in geometric mean (GM) with one or two standard deviations (SD). Specific IgE antibodies and determination of specific IgE levels were measu $\neg$ red by radioallergosorbent test (Phadezym RAST, Pharmacia Diagnostics).

\section{E. RAST results are expressed in «RAST Units» (PRU = Phadebas Rast Unit) as follows}

$1^{\text {st }}$ class $=$ IgE levels $<0.35 \mathrm{IU} / \mathrm{ml}$,

$2^{\text {nd }}$ class $=\operatorname{IgE}$ levels $>0.35 \mathrm{IU} / \mathrm{ml}$ and lesser than $0.7 \mathrm{IU} / \mathrm{ml}$, $3^{\text {rd }}$ class $=\operatorname{IgE}$ levels between $0,7 \mathrm{IU} / \mathrm{ml}$ and $17 \mathrm{IU} / \mathrm{ml}, 4^{\text {th }}$ class $=$ IgE levels higher than $17 \mathrm{IU} / \mathrm{ml}$.

Only RAST results > $0.35 \mathrm{IU} / \mathrm{ml}$ were considered positive.

The diagnosis of $\mathrm{AD}$ was made according to Hanifin and Rajka criteria [27]. The severity score of $A D$ was recorded according to the SCORAD index [28]. For the diagnosis of asthma, 3 episodes of wheezing without fever were re $\neg$ quired. For the diagnosis of rhinitis, nasal discharge and/or blockage occurring conᄀtinuously for at least 4 weeks plus the typical pale aspect of allergic mucosa on rhinos copy, without any sign of infective rhinitis in other relatives was required. For the diagnosis of FA, skin, gastrointestinal, and respiratory symptoms which occurred after OFC with the offending food.

\section{F. Challenge test}

At the end of the 4-6 wk period, OFCs were performed in the hospital under observation in a unit staffed to undertake emergency equipment. CM or eggs were administered as follows: a drop of CM (or of emulsioned raw egg, or a bit of bread) was put upon the inner border of the lower lip, and a further $5 \mathrm{ml}$ of CM (or $1 \mathrm{ml}$ of emulsioned raw egg, or $5 \mathrm{~g}$ of bread) were given after 5 minutes. One-hundred $\mathrm{ml}$ of CM or half-boiled egg, or $100 \mathrm{~g}$ of bread were given after 30 minutes. The reactions were defined as immediate if the first symptoms occurred within two hours of ingesting the food antigen, and de $\neg$ layed if the first symptoms occurred after two hours. If any symptoms sec $\neg$ ondary to the challenge test were observed, the challenge test in the hospital was terminated. After the last administration of the tested food the children were watched for at least four hours and then discharged. Data were statistically analyzed using the Student $\mathrm{t}$ and the $\mathrm{X} 2$ tests. The Fisher exact test was employed when possible.

\section{G. Study trial}

The following parameters were studied at the 3-years, 5-years and at the last folᄀlow-up: age; AD severity score; development of food tolerance; dura 7 tion of symptoms; respiratory allergy (asthma and/or rhinitis).

\section{H. Confounders}

We collected data regarding parental smoking habits, education, nationality and residence,

\section{Results}

The clinical characteristics of the 115 children at the first examination at a median age of 6 months are outlined in (Table 1), mean severity score of AD was 19 (8-81), and a typical disposition of skin lesion was present in 83 baᄀbies (72\%).

Table 1: Clinical characteristics of the 115 children with food-related atopic dermatitis (Follow-up $8 \mathrm{yrs}$ ) at the first examination.

\begin{tabular}{|c|c|c|}
\hline & No. & $\%$ \\
\hline \multicolumn{3}{|c|}{ Sex } \\
\hline Males & 66 & 57 \\
\hline Females & 49 & 43 \\
\hline $\mathrm{P}=0.015$ & & \\
\hline
\end{tabular}

\begin{tabular}{|c|c|c|}
\hline \multicolumn{2}{|c|}{ MA at AD onset in 115 children } \\
\hline $\begin{array}{c}\text { Before the } 4^{\text {th }} \text { mo } \\
\text { of life }\end{array}$ & 66 & 57 \\
\hline $\begin{array}{c}\text { Between the } 4^{\text {th }} \text { and } \\
6^{\text {th }} \text { mo }\end{array}$ & 39 & 34 \\
\hline After the 6th mo & 10 & 9 \\
\hline $\mathrm{P}=0.0001$ & & \\
\hline
\end{tabular}

\begin{tabular}{|c|c|c|}
\hline \multicolumn{3}{|c|}{ Disposition of skin lesion } \\
\hline Typical & 83 & 72 \\
\hline $\begin{array}{c}\text { Not typical (reverse } \\
\text { pattern) }\end{array}$ & 32 & 28 \\
\hline \multicolumn{2}{|c|}{ Age at the first feeding of a CM formula } \\
\hline At birth & 37 & 32 \\
\hline Before 3 months & 51 & 44.5 \\
\hline Before 6 months & 27 & 23.5 \\
\hline P= 0.0034 & & \\
\hline
\end{tabular}




\section{Association with AD}

AD was associated with CMA in 97/115 children (84.3\%) (Figure 1).

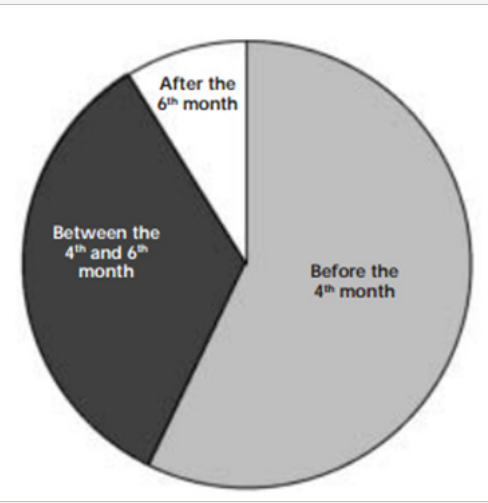

Figure 1: MA of $A D$ onset in 115 children followed-up 8 years, $p=0.0001$

\section{Family History}

FH of atopy was positive in 69 children (60\%) and negative in $46(40 \%)(p=0.0024)$.

\section{Sex}

There were 66 males (57\%) and 49 females (43\%) (p = $0.015)$.

\section{Age(s)}

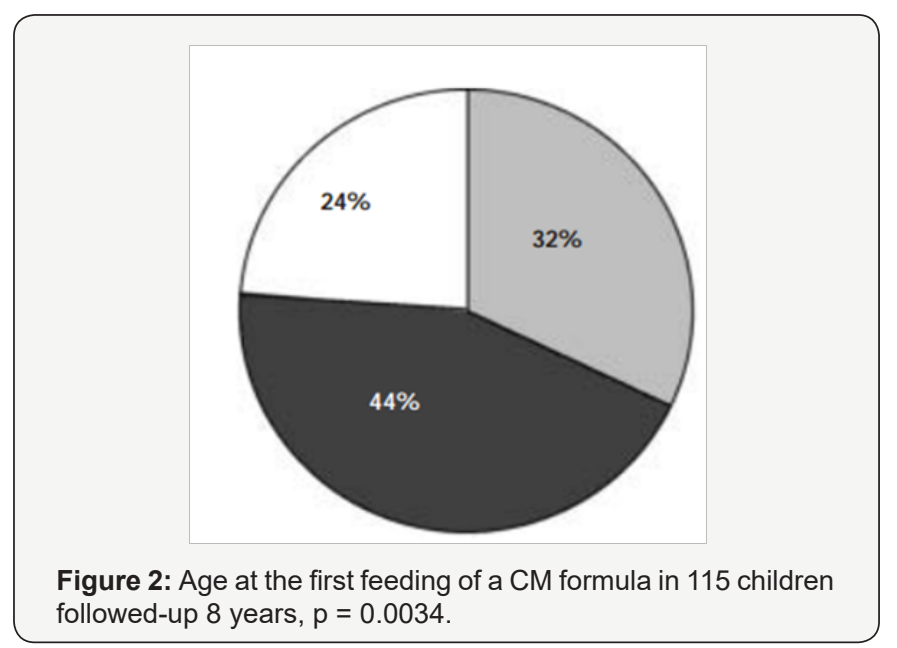

The MA at AD onset (median age $=3.5$ months, 5 days -150 days) was be 7 fore 4 months of life in 66 babies (57\%) between 4 and 6 months of life in 39 (34\%) and after 6 months of life in $10(9 \%)$ (Table 1) ( $p=0.0001)$. (Figure 2) shows the age of the first CM formula feeding. In 37 children (32\%) CM formulas were given since birth, in 51 (44.5\%) within the third month of life, and in $27(23.5 \%)$ before the sixth month of life ( $p=0.0034)$. As a con $\urcorner$ se-quence, 78 (68\%) infants were fed breast milk (BM) at birth ( $\mathrm{p}<=0.0000)$, and receiᄀved BM for about 3 months.

\section{SPTs and RAST}

All children had positive SPTs. SPT positivity score was $>2+$ in 92 children $(80 \%)(\mathrm{p}=0.0001)$. In detail, SPTs were positive to CM in 98 infants (85.7\%), to egg in 109 (95\%) and to wheat in 11 (9.5\%). Seven babies with no CMA and 6 with no egg allergy had positive SPTs to CM and egg, respective $\urcorner$ ly. More $\neg$ over, 36 children (31\%) were positive to inhalant allergens, and 24 (21\%) had multiple sensitizations to food and inhalant allergens.

RAST results for $\mathrm{CM} /$ other foods were of second class in $11 / 115(10 \%)$, third class in 21 (18\%), fourth class in $69(60 \%)$ and $14(12 \%)$ had a negative/first class RAST at the first testing $(\mathrm{p}=0.0001)$.

a) Total serum IgE levels: Total serum IgE levels were: GM 255 IU/ml, range 61-1110 IU/ml (2 SD).

b) Challenge tests: Due to previous severe anaphylactic reactions the OFCs to egg was not done in 7 children and to CM in 3. Altogether, OFCs with CM were positive in 106/ 115 children (92.2\%), with egg in 35 (30.4\%) and with wheat in $8(7 \%)$. Mul $\neg$ tiple sensitizations was present in $43 / 115$ (37.4\%) children: to $\mathrm{CM}$, egg and wheat in 27 cases, $\mathrm{CM}$ and wheat in $8, \mathrm{CM}$ and egg in 8 . The immediate allergic manifestations exhibited by the infants after the first ingestion of the offending foods and confirmed with the OFCs are outlined in (Table 2). In all children the allergic symptoms were immediate and appeared a few minutes after the ingestion of a small amount of the offending food.

Table 2: Allergic manifestations triggered by OFCs in the 115 infants.

\begin{tabular}{|c|c|c|}
\hline Symptoms triggered & No. & \% \\
\hline AD worsening & 48 & 41.5 \\
\hline $\begin{array}{c}\text { Gastrointestinal } \\
\text { symptoms }\end{array}$ & 19 & 16.5 \\
\hline Urticaria & 14 & 16.5 \\
\hline $\begin{array}{c}\text { Bronchospasm/ } \\
\text { wheezing }\end{array}$ & 7 & 6 \\
\hline Anaphylactic shock & 8 & 7 \\
\hline $\begin{array}{c}\text { Angioedema alone or } \\
\text { associated with AD, } \\
\text { asthma, Urticaria, } \\
\text { vomiting or diarrhea }\end{array}$ & & \\
\hline
\end{tabular}

\section{c) Confounders}

All families were of Italian descent. The incidence of household cigarette smokers was very high (77\%) but without differences among families living in Rome or in the province, or related to education.

\section{d) Follow-up}

At the last follow-up, the children were 8 years +6 months -13 years +2 months old (median age 9 years +4 months). Clinically, skin lesions cleared up in 66 (57\%) children, whereas persisted in $49(43 \%)$. As regards RAST changes, 16 (24\%) of improved 
children were RAST-negative, $24(36 \%)$ had a $2^{\text {nd }}$ class RAST, 16 $(24 \%)$ a $3^{\text {rd }}$ class RAST, and $10(15 \%)$ a 4 th class RAST. Among the intolerant children, $8(16 \%)$ had a 2 nd class RAST, $9(18 \%)$ a 3rd class RAST, and $31(63 \%)$ a $4^{\text {th }}$ class RAST, RAST was not repeated only in a not tolerant child.

\section{e) Natural History}

Food tolerance was present in 66 children (57\%). The MA for tolerance to CM was 7 years +11 months, to egg 6 years +6 months, and to wheat 7 years +2 months. Therefore the children with CMA achieved tolerance at an age significantly higher than the children with egg or wheat allergy. We then studied the correlation between symptoms and development of tolerance in the 115 children (Table 3). During the follow-up there were significant differences between the 60 tolerant children and the 55 with persist 7 ing $\mathrm{AD}$ including either the symptoms manifested at the first examination, or the development of other sensitizations. Persistent intolerance to the offending food was found to be significantly associated with AD and angioedema $(\mathrm{p}=0.0001)$. Moreover, a significant relationship was found between loss of FA and a high presence of asthma (30\%) (Table 4) $(\mathrm{p}=0.022)$.

Table 3: Correlation between symptoms and development of tolerance during the follow-up in the 115 children.

\begin{tabular}{|c|c|c|c|c|}
\hline \multirow{2}{*}{ Clinical features } & \multicolumn{2}{|c|}{60 tolerants } & \multicolumn{2}{c|}{$\begin{array}{c}\text { 55 not } \\
\text { tolerants }\end{array}$} \\
\hline & No. & \% & No. & \% \\
\hline AD+ FA & 52 & 60 & 48 & 55 \\
\hline Asthma & 18 & 30 & 28 & 47 \\
\hline $\begin{array}{c}\text { Multiple } \\
\text { sensitization }\end{array}$ & 2 & 3 & 4 & 7 \\
\hline P=0.0001 & 13 & 22 & 22 & 40 \\
\hline
\end{tabular}

Table 4: Correlation between tolerance and development of asthma during the follow-up in the 115 children.

\begin{tabular}{|c|c|c|}
\hline \multicolumn{3}{|c|}{ Development of asthma } \\
\hline & No. & $\%$ \\
\hline Tolerants & $18 / 60$ & 30 \\
\hline Not tolerants & $28 / 55$ & 58 \\
\hline $\mathrm{P}=0.022$ & & \\
\hline
\end{tabular}

Among the improved children 18 (30\%) developed allergy to inhalants (8 to Lolium perenne, 10 to Der p), and 28 (51\%)

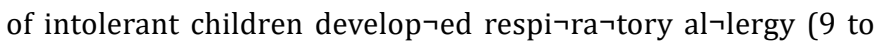
Lolium perenne, 19 to Der p). There was no difference in the MA of these 3 groups. The study of the correlation between sensitizing foods and development of additional allergies (Table 5) revealed that 58/106 children with CMA developed several sensitizations during the follow-up ( $p=0.0047)$. At the followup after eight years (Table 6), when the children had a median age of 9 years +4 months, it is true that six more children lost FA $(57 \%)(p=0.003)$, but $49(43 \%)$ still had symptoms due to
FA ( $p=0.0025)$. Of these 49 children, 30 suffered from CMA and 19 from egg allergy ( $p=0.0263$ ), in addition they have developed more multiple sensitizations $(p=0.035)$. However a greater number of children, 62 (54\%), suffered from asthma, an in $\neg$ crease of $74 \%$ ( $p=0.0345)$.

Table 5: Correlation between sensitizing food and development of additional food allergies during the follow-up in the 115 children.

\begin{tabular}{|c|c|c|}
\hline Foods & \multicolumn{2}{|c|}{ Development of other allergies } \\
\hline & No. & $\%$ \\
\hline CM & $58 / 106$ & 55 \\
\hline Whg & $11 / 35$ & 31 \\
\hline $\begin{array}{c}\text { Multiple } \\
\text { sensitizations }\end{array}$ & $1 / 8$ & 12 \\
\hline $\mathrm{P}=0.0047$ & $16 / 43$ & 37 \\
\hline
\end{tabular}

Table 6: Clinical course of 115 children with food-related AD (Followup 8 years).

\begin{tabular}{|c|c|c|}
\hline Outcome & No. & \% \\
\hline Resolved & 66 & 57 \\
\hline Persisting & 49 & 43 \\
\hline Respiratory allergy & 62 & 54 \\
\hline
\end{tabular}

Table 7: Age of onset of $A D$ and outcome in 115 children with foodrelated $A D$ according to the age of onset (Follow-up 8 years).

\begin{tabular}{|c|c|c|c|c|}
\hline Outcome & \multicolumn{4}{|c|}{ Age of onset (months) } \\
\hline & \multicolumn{2}{|c|}{$<6$} & \multicolumn{2}{c|}{$>\mathbf{6}$} \\
\hline & No. & \% & No. & \% \\
\hline Resolved & 53 & 80 & 13 & 20 \\
\hline Persisting & 19 & 39 & 30 & 61 \\
\hline $\mathrm{P}=0.0001$ & & & & \\
\hline
\end{tabular}

Table 8: RAST class at diagnosis and at last follow-up and according to the development of tolerance in the 115 children.

\begin{tabular}{|c|c|c|c|c|}
\hline \multicolumn{5}{|c|}{ RAST classes } \\
\hline & $\mathrm{Neg} / 1^{\text {st }}$ & $2^{\text {nd }}$ & $3^{\text {rd }}$ & $4^{\text {th }}$ \\
\hline \multicolumn{5}{|c|}{ No. of children } \\
\hline \multicolumn{5}{|c|}{ At diagnostic } \\
\hline Tolerants & 13 & $3(5 \%)$ & $10(17 \%)$ & $34(57 \%)$ \\
\hline $\begin{array}{c}\text { Not } \\
\text { tolerants }\end{array}$ & 1 & $8(15 \%)$ & $11(20 \%)$ & $35(64 \%)$ \\
\hline \multicolumn{5}{|c|}{ Last follow up } \\
\hline Tolerants & 16 & $24(36 \%)$ & $16(24 \%)$ & $10(15 \%)$ \\
\hline $\begin{array}{c}\text { Not } \\
\text { tolerants }\end{array}$ & 1 & $8(16 \%)$ & $9(18 \%)$ & $31(63 \%)$ \\
\hline
\end{tabular}

At diagnosis: tolerants vs not tolerants, $p=0.0001$, Last follow up: tolerants vs not tolerants, $p=0.0001$, not tolerants NS. 
We then noted a significant relationship between the age of onset of AD and the outcome of skin lesions (Table 7). Among the improved children, 53 (80\%) were less than 6 months old when AD first appeared, unlike 30 children (61\%) with an onset of AD after 6 months ( $p=0.0001)$. There was a significant relationship also between RAST results at the first examination and at the last follow up. RAST classes are reported in (Table 8) according to the outcome of children, with very significant differences.

\section{Discussion}

We have enrolled 115 highly atopic children (SPTs, RAST and OFC re $\neg$ sults), evaluating clinical features typical of CMA, either systemic such as anaphy $\neg$ laxis, or involving major shock organs including the gastrointestinal tract, skin, and respiratory tract, until the last follow-up. In this long-term, prospective study 115 infants were carefully followed-up with regular controls.. As regards CMA incidence, a recent report found a mean of $2.16 \%$ in 15 studies in healthy and preterm infants, and of $14.72 \%$ in 3 studᄀies in at risk babies [29]. The results of this study confirm that $\mathrm{AD}$ is a chronic, multifactorial disease, as shown by all children suffering from FA, and by the elimination-provocation tests. Even if the children had a median age of 9 years +4 months at the last follow-up, 58\% of them were still affected with $\mathrm{AD}$, moreover $54 \%$ of children developed respiratory allergy. These figures concur with the data re $\neg$ ported by other investigators [1,14,18,22,30,31,33-35].

Table 9: Parameters predicting an unfavorable outcome.

\begin{tabular}{|c|c|}
\hline Unfavorable factors & Statistics \\
\hline $\begin{array}{c}\text { Family history of atopy, positive } \\
\text { vs negative }\end{array}$ & $\mathrm{P}=0.0024$ \\
\hline Male sex & $\mathrm{P}=0.015$ \\
\hline SPT results, positive vs negative & $\mathrm{P}=0.0001$ \\
\hline RAST results, positive vs negative & $\mathrm{P}=0.0001$ \\
\hline $\begin{array}{c}\text { AD onset before the } 4^{\text {th }} \text { month } \\
\text { of life }\end{array}$ & $\mathrm{P}=0.0001$ \\
\hline $\begin{array}{c}\text { First feeding of a CM formula } \\
\text { before the } 3^{\text {rd }} \text { month }\end{array}$ & $\mathrm{P}=0.0034$ \\
\hline $\begin{array}{c}\text { Correlations between symptoms } \\
\text { and development of tolerance }\end{array}$ & $\mathrm{P}=0.0001$ \\
\hline $\begin{array}{c}\text { Between tolerance and } \\
\text { development of asthma }\end{array}$ & $\mathrm{P}=0.022$ \\
\hline $\begin{array}{c}\text { Between tolerance and } \\
\text { development of additional } \\
\text { allergies }\end{array}$ & $\mathrm{P}=0.0047$ \\
\hline Age of onset of AD and outcome & $\mathrm{P}=0.0001$ \\
\hline $\begin{array}{c}\text { RAST class at diagnosis and } \\
\text { at last follow up at diagnosis: } \\
\text { tolerants vs not tolerants } \\
\text { tolerants }\end{array}$ & $\mathrm{P}=0.0001$ \\
\hline $\begin{array}{c}\text { Last follow up: tolerants not } \\
\text { (a) }\end{array}$ & $\mathrm{P}=0.0001$ \\
\hline
\end{tabular}

In several studies [6-21] the reported rates of child improvement vary remarkably, ranging from $11 \%$ [6] to $90 \%$ [19], however seborrhoic dermatitis was overrepresented in the latter study. Several reports have observed a favorable outcome in $40-50 \%$ of children at $13-15$ years of follow-up $[14,16$ $18,30,31,37]$ while in others the consensus is not unanimous $[6,9,12,14]$. In a Swedish study, children with AD retained their eczema as adults [12]. We have found several parameters predicting a poorer outcome (Table 9), thus confirming the results of the above alluded to studies on AD natural history. These have selected numerous factors as negatively predicting the outcome. As follows: positive FH for atopy, male sex, widespread or not typical (reverse pattern) skin lesions, early AD on ᄀset, male sex, association with CMA, while in a previous study positive FH for atopy, sex, but SPT res $\neg$ ponses, and severity of skin lesions had no predictive value [7].

Several studies have emphasized the relationship between CM formula feedᄀing and AD development [38,40-42]. A prospective study [15] showed that CM formula feeding was an unfavorable factor for $\mathrm{AD}$ development [15,24,38-42]. We em $\neg$ phasize that $76.5 \%$ of the children of the present study were given $\mathrm{CM}$ formulas before the sixth month of life. Others stress that FA plays an important role in AD [1,26,41,43,44-57]. Eighty percent of the children had serum total IgE levels higher than 2 SDs for age and $88 \%$ had positive IgE to food allergens. It was reported that $80 \%$ of AD is due to IgE-mediated al $\neg$ ler $\neg$ gy $[1,25,38]$. Sampson et al. [53]. Showed that such patients generally have elevated serum levels of IgE antibodies, and that such react $\neg$ ions are ac $\neg$ com $\neg$ panied by increased amounts of circulating his 7 tamine [58]. Atherton et al. [44] suggest that the role of foods may be more critical in the beginning of the condition than later on.

In support of this unfavorable relationship between CM feeding and $\mathrm{AD}$ deาvelาopment, we report in this study 37 children (32\%) that were fed CM at birth and 78 (68\%) within or after the sixth month of life, as a complement or a substitu 7 te of BM feeding. Following an early exposure to CM formulas the allergic features appeared, hence significantly influencing the atopy persistence $(p=0.0021)$. Furthermore, previous studies have enhanced the crucial role played by FA in AD pathogenesis $[1,17,23,42,43-53]$. In this cohort, all children have shown SPTs and at least 101/115 RAST results positive for foods, allowing toconclude for an IgE-mediated AD. This finding represents an important contributing factor in $80 \%$ of children with IgEmediated $\mathrm{AD}[17,45]$, in whom IgE antibodies are usually di $\neg$ rected against the more rele $\neg$ vant foods $[17,53]$, accompanied by increased levels of circu ᄀlating histamine [54] As many as 16 children $(13,9 \%)$ reacted to 2 and $27(23.5 \%)$ to 3 foods, thus $88(76.5 \%)$ reacted to 1 or 2 foods, and multiple sensitizations developed in 43 children (37.4\%), in accordance with previous findings [17]. The man רagement of CMA is based, whatever the 
clinical features, on a diet excluding both CM and closely related foods, following which the paᄀtients markedly improve [45].

Therefore the elimination of offending foods repre $\urcorner$ sents the basal FA management, either because it can reverse the dise 7 ase development, or can favor the revival of a complete tolerance possibly followed by a normal re-feeding. It is not yet completely known how food tolerance could be restored as a result of an appropriate, and carefully constructed diet. For example Jar $\neg$ rett [56] and Firer et al. [57] have demonstrated that feeding a causative agent, such as CM, even in small doses, triggers an IgE-mediated response, thus altering the immune system, which could instead redress after a diet period. A controlled study has shown that the elimina $\neg$ tion of the offending food for one to two years, but also restrict 7 ed to 3-6 months, can ameliorate the symptoms, even severe, related to the assumption of the of $\neg$ fending food [1].

The MA for tolerance to CM was 7 years +11 months, to egg 6 years +6 months, and to wheat 7 years +2 months. Therefore the children with CMA achieved tolerance at an age significantly higher than the children with egg or wheat allergy. At the last follow-up, the tolerance to CM and egg was achieved by $45 \%$ and $69 \%$ of children, respectively, however multiple sensitizations were frequent, despite ongoing pharmacological and dietetic management; thus stressing that $\mathrm{AD}$ is a multifactorial disease. However, CM is so a potent allergen that a drop posed on the lower lip may trigger anaphylaxis [36]. The children with hypersensitivity to 2 or more foods achieved tolerance later to CM, egg or other foods, as already described $[7,17,31]$. Sixty-six percent of the children with healing lost FA totally or partially, while $43 \%$ of the children with pers $\neg$ isting $\mathrm{AD}$ were still sensiᄀtive to the of $\neg$ fending foods ( $p=0.0001)$. These data are in agreement with those of Samp $\neg$ son et al. [17].

The early age of onset of $\mathrm{AD}(<6$ months) was significantly associated with the lost of FA $(\mathrm{p}=0.0001)$. According to several authors, both the age of on $\neg$ set of AD after the sixth month of life $(7,19)$ and the not typical or widespread skin lesions $[7,14$ $16,19,33$ ] had a significant value in predicting the persistence of AD. To our knowledge, several studies have reported an association with respiratory allergy, including this one [5-10,12$15,18,20,21]$, registering a $42,5 \%$ prevalence for asthma and of $48,3 \%$ for AR. Therefore, in children with AD ap-propriate strategies should prevent the development of respiraᄀtory aller gy. Positive SPTs and/or IgE to inhalant allergens at the first exam $\neg$ ina $\neg$ tion appeared to have a predictive value for the development of respiraᄀtory al $\neg$ lergy (asthma and/or rhinitis) [7].

In addition, if there is a significant association of AD with CMA, or with egg allergy, the clinical improvement and food tolerance are attained 2-5 years later $[3,4,17,35]$, whereas hypersensitivity to other foods, such as fish, ce-reals or nuts is lost even later $[3,17,37]$. It is generally agreed that the $\mathrm{AD}$ outcome appears to be more favorable when the children leave CM hyperse $\neg$ nsitivity [17], as particularly stressed by a study where only one child out of 32 was still intolerant at the last folᄀlow-up [35], unlike the present study, and a previous one [3]. In keeping with our results, it is significant that $22 \%$ to $24 \%$ of tolerant children had low/negative specific IgE (IgEs) at the first visit and the last follow-up ver $\neg$ sus $2-11 \%$ of the children with persisting $\mathrm{AD}$, which could be a predictive factor of tolerance.

In our paper on the so-called BM allergy [38], at the last follow-up, a greater number of tolerant children were RASTnegative, versus those with persisting FA, compared to the first control where the ratio was specularly inverse ( $p<<0.0001)$. In the parallel study on the natural history of FA [3], the proportion of negative RASTs increased by $82.2 \%$ in the tolerant and by $42.5 \%$ in the not tolerant children $(\mathrm{p}=0.0001)$. Thus, in these studies, RAST turned negative in a significant part of tolerant children, enabling us to conclude that even the variations of RAST values can be predictive of tolerance.

In agreement with literature data, a high genetic risk for atopy existed in our cohort. We would like to stress that the above data do not strengthen the diffuse opinion of FA improving in a major part of children during the first years of life [14,16-18,30,31]. However, 8 out of 21 children (38\%) developed asthma during the follow-up [38]. In this study $30 \%$ of children had asthma, which increased up to $54 \%$ during the long follow-up. Above all the influence of foods can foreshadow a more remarkable risk of sensitization if they are administered more in the initiation of disease than after its induction [44]. Some indirect support to this assumption could be pro vided by the observation that SPT reactivity to foods is particularly critiาcal in very young babies with AD, subsequently fading gradually away [55].

We rather emphasize the importance of recommending to parents of neonates at risk for atopy a prolonged breastfeeding and a gradual weaning, which are frequently reported to be able to prevent or delay the develᄀop-ment of atopic disease. Breastfeeding, if feasible, should be preserved or resumed, with the greatest care of prescribing a diet free of $\mathrm{CM}$ and related sources to the nursing mother. As previously alluded to, in BM exists a complete supply of nutritive and immune factors, nearly unappreciated until some time ago, whereas over the last few years the study of the pertinent mechanisms is unfolding an always growing corpus of experimental results [29,58-60].

Additional, possible areas of intervention in children at risk due to parental atopy.would logically include avoidance also of cereals [61], and egg [62] as risk factor for an increasing incidence of $\mathrm{AD}$, or a grass pollen asthma [63], the asthma risk is shared by the association of AD with FA within 24 months of age [64] and the sensitivity to CM and/or egg [3]. The avoidance of maternal smoke during and after pregnancy is advocated [65], as well as the reduction of exposure to relevant allergens, above all house dust mites in children at risk [61] and cats in all children. 


\section{Conclusion}

This study confirms that the natural history of IgE-mediated FA is less favorable than it is usually believed, especially in atopic children. These children may have CD137, notably involved in T-cell activation and differen-tiation, and expressed by blood and tissue eosinophils [66]. Consequently, no firm evidence that FA is often «lost» over time [67] is in agreement with the study of these 115 children, where the CM allergens show that not much is necessary to set in motion the atopic march, and to maintain it, at least for eight years. This is not surprising because children with more severe courses are referred to our department by pediatricians and dermatologists for further investigations.

\section{Reference}

1. Bock SA (1985) Natural history of severe reactions to foods in young children. J Pediatr 107(5): 676-680.

2. Dannaeus A, Johansson SG (1979) A follow-up study of infants with adverse reactions to cow's milk. I. Serum IgE, skin test reactions and RAST in relation to clinical course. Acta Paediatr Scand 68(3): 377-382.

3. Cantani A, Bellioni B, Ragno V, et al. (1990) Epidemiologia e storia naturale dell'allergia alimentare: Follow-up di 88 bambini fino a 14 anni. Aggiorn Pediatr 41: 321-332.

4. Dannaeus A, Inganås M (1981) A follow-up study of children with food allergy. Clinical course in relation to serum IgE- and IgG-antibody levels to milk, egg and fish. Clin Allergy 11(6): 533-539.

5. Åberg N, Engström I (1990) Natural history of allergic diseases in children. Acta Paediatr Scand 79(2): 206-211.

6. Bardare M, Zani G, Magnolfi C (1992) Evoluzione della dermatite atopica ad insorgenza nei primi anni di vita. In: Allergie alimentari. Roma: Fisons Italchimici SpA 157-165.

7. Businco L, Ziruolo MG, Ferrara M, Nicolletta Benincori, Atonella Muraro, et al. (1989) Natural history of atopic dermatitis in childhood. Allergy 44(9): 70-78.

8. Foucard T (1991) Allergy and allergy-like symptoms in 1050 medical students. Allergy 46(1): 20-26.

9. Guillet G, Guillet MH (1992) Natural history of sensitizations in atopic dermatitis. A 3-year follow-up in 250 children: food allergy and high risk of respiratory symptoms. Arch Dermatol 128(2): 187-192.

10. Kissling S, Wüthrich B (1994) Localization, manifestations, and micromanifestations of atopic dermatitis in young adults. Personal follow-up 20 years after diagnosis in childhood. Hautarzt 45(6): 368371

11. Kissling S, Wüthrich B (1993) Verlauf der atopischen Dermatitis nach Kleinkindesalter. Hautarzt 44: 569-573.

12. Kjellman B, Hesselmar B (1994) Prognosis of asthma: a cohort study into adulthood. Acta Paediatr 83(8): 854-861.

13. Linna O, Kokkonen J, Lahtela P, Tammela O (1992) A 10-year prognosis for generalized infantile eczema. Acta Pædiatr 81(12): 1013-1016.

14. Musgrove K, Morgan JK (1976) Infantile eczema. A long-term follow-up study. Br J Dermatol 95(4): 365-372.

15. Queille-Roussel C, Raynaud F, Saurat JH (1985) A prospective computerized study of 500 cases of atopic dermatitis in childhood. Acta Derm Venereol suppl 114: 87-92.

16. Rystedt I (1985) Prognostic factors in atopic dermatitis. Acta Dermatol Venereol 65(3): 206-213.
17. Sampson HA, McCaskill CC (1985) Food hypersensitivity and atopic dermatitis: Evaluation of 113 patients. J Pediatr 107(5): 669-675.

18. Van Hecke E, Leys G (1981) Evolution of atopic dermatitis. Dermatologica 163(5): 370-375.

19. Vickers CFH (1980) The natural history of atopic eczema. Acta Dermatovener suppl 92: 113-115.

20. Wüthrich B, Schadel P (1983) Die Neurodermitis atopica nach dem Kleinkindesalter. Eine katamnestische Untersuchung. Z Hautkr 58: 1013-1023.

21. Wüthrich B, Oehme J (1984) The prognosis of atopic dermatitis after infancy. Hexagon 12: 1-8.

22. Lucenti P, Cantani A (1991) Diagnosis and treatment of food allergy Eur Rev Med Pharmacol Sci 13: 99-103.

23. Businco L, Cantani A, Monteleone AM, Ziruolo MG (1988) Atopic dermatitis in children: an update. Folia Allergol Immunol Clin 35: 4151.

24. Pepys J (1975) Skin testing. Br J Hosp Med 14: 412-417.

25. Dreborg S, Backman A, Basomba A (1989) Skin tests used in type I allergy testing. Position paper. Allergy 44 (suppl 10): 1-59.

26. Aas K, Belin L (1974) Suggestions for biologic qualitative testing and standardization of allergen extracts. Acta Allergol 29: 238-240.

27. Hanifin JM, Rajka G (1980) Diagnostic features of atopic dermatitis. Acta Derm Venereol 92: 44-47.

28. Stalder JF, Taïeb A, Atherton DJ (1993) Severity scoring of atopic dermatitis: the SCORAD index. Dermatology 186(1): 23-31.

29. Cantani A (2000) Allergologia ed immunologia pediatrica: Dall'infanzia all'adolescenza. Roma: Verduci Editore 2000.

30. Meenan FOC (1959) Prognosis in infantile eczema. Ir J Med Sci 398 79-83.

31. Vowles M, Warin RP, Apley J (1955) Infantile eczema: observations on natural history and prognosis. Br J Dermatol 67(2): 53-59.

32. Stifler WC (1965) A twenty-one-year follow-up of infantile eczema. J Pediatr 66: 166-167.

33. Roth HL, Kierland RR (1964) The natural history of atopic dermatitis. Arch Dermatol 89(2): 209-214.

34. Rystedt I (1985) Long term follow-up in atopic dermatitis. Acta Dermatol Venereol 114 (suppl): 117-120.

35. Rystedt I (1985) Hand eczema and long term prognosis in atopic dermatitis. Acta Dermatol Venereol 117: 1-59.

36. Cantani A, Gagliesi D (1996) Severe reactions to cow's milk in very young infants at risk of atopy. Allergy Asthma Proc 17(4): 205-208.

37. Cantani A, Micera M (1999) Gli allergeni del latte vaccino favoriscono la marcia atopica: uno studio su 32 lattanti ( $2^{\underline{a}}$ parte). Aggiorn Pediatr 2: 73-78.

38. Cantani A, Ragno V, Businco L (1991) Natural history of IgE-mediated food allergy in fully breast-fed babies: Report of twenty-one cases (Follow-up to 19 years). Pediatr Allergy Immunol 2(3): 131-134.

39. Businco L, Cantani A, Bruno G (1987) Results of dietary and environmental measures for the prevention of atopy in "at risk" babies. In Chandra RK (ed) Food Allergy. St John's: Nutr Res Education Foundation 361-372.

40. Businco L, Cantani A, Meglio P, Bruno G (1987) Prevention of atopy: Results of a long- term (7 months to 8 years) follow-up. Ann Allergy 59/5 (Part 2): 183-186. 
41. Chandra RK (1987) Environmental engineering in the prevention of atopic disease: how early is early enough? In Chandra RK (ed.) Food Allergy. St John's: Nutr Res Education Foundation 373-387.

42. Saarinen UM (1984) Prophylaxis for allergic disease: Role of infant feeding. Clin Rev Allergy 2(2): 151-167.

43. Talbot FB (1918) Eczema in childhood. Med Clin North Am 1: 985-996.

44. Atherton DJ, Sewell M, Soothill JF, Wells RS, Chilvers CE (1978) A double-blind controlled crossover trial of an antigen-avoidance diet in atopic eczema. Lancet 1: 401-403.

45. Sampson HA (1983) Role of immediate food hypersensitivity in the pathogenesis of atopic dermatitis. J Allergy Clin Immunol 71(5): 473480.

46. Brostoff J, Carini C, Wraith DG, Johns P (1979) Production of IgE complexes by allergen challenge in atopic patients and the effect of sodium cromoglycate. Lancet 1(8129): 1268-1270.

47. Glaser J (1955) The prophylaxis of allergic disease with special reference to the newborn infant. NY State J Med 55(18): 2599-2605.

48. Glaser J, Johnstone DE (1953) Prophylaxis of allergic disease in the newborn. JAMA 153(7): 620-622.

49. Grulee CG, Sanford HN (1936) The influence of breast and artificial feeding on infantile eczema. J Pediatr 9(2): 223-225.

50. Jackson PG, Baker RWR, Lessof MH, Ferrett J, MacDonald DM (1981) Intestinal permeability in patients with eczema and food allergy. Lancet 1(8233): 1285-1286.

51. Rajka G (1975) Atopic dermatitis. In Rook A, ed. Major problems in dermatology, vol 3. London: WB Saunders Co 46-130.

52. Ring J, Senter T, Cornell RC, Arroyave CM, Tan EM (1978) Complement and immunoglobulin deposits in the skin of patients with atopic dermatitis. Br J Dermatol 99(5): 495-501.

53. Sampson HA, Albergo R (1984) Comparison of results of skin tests, RAST, and double-blind, placebo-controlled food challenges in children with atopic dermatitis. J Allergy Clin Immunol 74(1): 26-33.

54. Sampson HA, Jolie PL (1984) Increased plasma histamine concentrations after food challenges in children with atopic dermatitis. N Engl J Med 311(6): 372-376.

55. Van Asperen PP, Kemp AS, Mellis CM (1984) Skin test reactivity and clinical allergen sensitivity in infancy. J Allergy Clin Immunol 73(3): 381-386.
56. Jarrett EEE (1977) Activation of IgE regulatory mechanisms by transmucosal absorption of antigen. Lancet 2: 223-225.

57. Firer MA, Hosking CS, Hill DJ (1981) Effect of antigen load on development of milk antibodies in infants allergic to milk. BMJ 283(6293): 693-696.

58. Goldman AS (1993) The immune system of human milk: antimicrobial, antiinflammatory and immunomodulating properties. Pediatr Infect Dis J 12(8): 664-671.

59. Hanson LÅ (1998) Breastfeeding provides passive and likely longlasting active immunity. Ann Allergy Asthma Immunol 81(6): 523-527.

60. Slade HB, Schwartz SA (1987) Mucosal immunity: The immunology of breast milk. J Allergy Clin Immunol 80 (3 Pt 1): 348-358.

61. Fergusson DM, Horwood J (1994) Early solid feeding and recurrent childhood eczema: A 10-year longitudinal study. Pediatr Allergy Immunol 5(6): 44-47.

62. Huang JL, Chen CC, Kuo ML, Hsieh KH (2001) Exposure to a high concentration of mite allergen in early infancy is a risk factor for developing atopic dermatitis. A 3-year follow-up study. Pediatr Allergy Immunol 12: 11-16.

63. Armentia A, Bañuelos MI, Arranzi V, Del Villar V, Martín-Santos JM, et al. (2001) Early introduction of cereals into children's diets as a risk of grass pollen asthma. Clin Exp Allergy 31(80): 1250-1255.

64. Laan MP, Baert MRM, Bijlt AMH, Vredendaal AE, De Waard-van der Spek FB, et al. (2000) Markers for early sensitization and inflammation in relation to clinical manifestations of atopic disease up to 2 years of age in 133 high-risk children. Clin Exp Allergy 30(7): 944-953.

65. Cantani A (2000) Epidemiology of cigarette smoke in the homes of asthmatic children. J Allergy Clin Immunol 105: S35.

66. Heinisch IV, Bizer C, Volgger W, Simon HU (2001) Functional CD137 receptors are expressed by eosinophils from patients with IgEmediated allergic responses but not by eosinophils from patients with non-IgE-mediated eosinophilic disorders. J Allergy Clin Immunol 108(1): 21-28.

67. Sampson HA (1999) Food allergy. Part 2: Diagnosis and management, J Allergy Clin Immunol 103(6): 981-989.

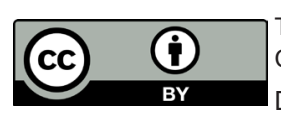

This work is licensed under Creative Commons Attribution 4.0 Licens

DOI: 10.19080/GJO.2017.03.555618

\section{Your next submission with Juniper Publishers will reach you the below assets}

- Quality Editorial service

- Swift Peer Review

- Reprints availability

- E-prints Service

- Manuscript Podcast for convenient understanding

- Global attainment for your research

- Manuscript accessibility in different formats

( Pdf, E-pub, Full Text, Audio)

- Unceasing customer service

Track the below URL for one-step submission https://juniperpublishers.com/online-submission.php 